\title{
GAMBARAN UPAYA KESELAMATAN DAN KESEHATAN KERJA DALAM PENGGUNAAN PESTISIDA
}

\author{
Made Canita Rianty ${ }^{1}$, I Wayan Sudiadnyana ${ }^{2}$
}

\begin{abstract}
Potencial hazards that the threaten safety and health agricultural sector one of them is the use of pesticides. The pesticides are not controlled can make some trobles of health and environment pollution. The purpose of this study is to know description of occupational safety and health efforts in the use of pesticides of farmer group "Kube Amerta Abadi" In Candikuning Baturiti, Tabanan regency. This study is descriptive study. The sampling using a saturated sampling technique, in wich all members of the population are sampled. The data obtained through by interview and check up the cholinesterase of 15 members of farmer groups. The result of study are indicated that from 15 farmers, 14 farmers have a good effort of OHS planning phase. The effort of OHS implementation phase of 15 farmers all have a good effort of OHS. From 15 farmers, 9 of the farmers have the effort of OHS the bad post implementation phase, and 6 farmers have the effort of OHS the good post implementation phase. The effort of OHS in the use of pesticides 15 farmers, 8 farmers have the effort of OHS is good and 7 farmers have the effort of OHS moderate ability. From the check of cholinesterase, 4 farmers have a mild toxic and 11 farmers have suffered moderate toxic.
\end{abstract}

Keywords :The effort of OHS, Farmer, Pesticide Poisioning.

Indonesia merupakan negara agraris yang sebagian besar penduduknya sebagai petani dengan demikian dominan tenaga kerja Indonesia pada sector pertanian. Berdasarkan data ILO ASEAN, kecelakaan kerja di Indonesia pada industri pertanian menduduki tempat kedua atau ketiga terbesar dibanding industri lain. ${ }^{1}$ Potensi bahaya yang mengancam pada sektor ini utamanya pada petani tanaman pangan dan holtikultura salah satunya adalah penggunaan pestisida. Petani menggunakan pestisida untuk membasmi hama tanaman dalam meningkatkan hasil panen, namun seringkali tidak mempertimbangkan dampak kesehatan baik bagi petani sendiri dan lingkungan ${ }^{2}$.

$$
\text { Penggunaan pestisida yang }
$$

berlebihan dan tidak sesuai aturan akan dapat menimbulkan dampak negatif di antaranya kasus keracunan pada manusia, Data dari WHO menunjukkan 500 ribu sampai 1 juta orang per tahun di seluruh dunia telah mengalami keracunan pestisida dan sekitar 500 - 1000 diantaranya mengalami dampak yang sangat fatal seperti kanker, cacat, kemandulan dan gangguan pada hepar ${ }^{3}$.

Kabupaten Tabanan adalah salah satu dari 9 Kabupaten/ Kota yang ada di 
Provinsi Bali memiliki unggulan di bidang pertanian kerena sebagian besar mata pencaharian, serta penggunaan lahan di wilayah Tabanan masih didominasi bidang pertanian. Desa Candikuning termasuk dalam wilayah Kecamatan Baturiti, Tabanan, merupakan daerah dataran tinggi dimana sekitar $80 \%$ penduduk desa ini bekerja disektor pertanian holtikultura. Salah satu kelompok tani ada di wilayah tersebut adalah "Kube Amerta Abadi" yang berdiri sejak tahun 2015 dengan jumlah anggota sebanyak 15 orang.

Berdasarkan uraian di atas perlu dilakukan penelitian tentang "Gambaran Upaya Keselamatan dan Kesehatan Kerja Pada Kelompok Tani "Kube Amerta Abadi" di Desa Candikuning, Baturiti, Tabanan Tahun 2018.

\section{Metode}

Jenis penelitian yang digunakan adalah studi deskriptif pendekatan potong lintang (cross sectional) yaitu rancangan penelitian dengan melakukan pengamatan atau pengukuran pada saat bersamaan.

Unit analisis dalam penelitian ini adalah upaya keselamatan dan kesehatan kerja petani dalam penggunaan pestisida yang dilakukan oleh setiap anggota Kelompok Tani Kube Amerta Abadi, Desa Candikuning, Baturiti, Tabanan.

Jenis data dalam penelitian ini menggunakan data primer yaitu data dari hasil wawancara dan pengukuran cholinesterase darah.

\section{Hasil Dan Pembahasan}

\section{Karakteristik Petani}

a. Umur Petani

Tabel 1.

Karakteristik Petani Berdasarkan Umur

\begin{tabular}{ccc}
\hline Umur & Frekuensi & $\begin{array}{c}\text { Presentase } \\
(\%)\end{array}$ \\
\hline $36-45$ tahun & 5 & 33 \\
$46-55$ tahun & 8 & 53 \\
$56-65$ tahun & 1 & 7 \\
$>65$ tahun & 1 & 7 \\
\hline Total & 15 & 100 \\
\hline
\end{tabular}

Berdasarkan tabel 2 dapat diketahui bahwa umur petani terbanyak 9 $(60 \%)$ merupakan petani berumur $40-50$ tahun.

b. Masa Kerja

Berdasarkan sampel yang diteliti bahwa seluruh anggota telah menjadi petani lebih dari 10 tahun.

\section{Implementasi Upaya K3 dalam Penggunaan Pestisida}

Diketahui melalui wawancara sesuai dengan tahapan perencanaan, pelaksanaan dan pasca pelaksanaan terhadap 15 orang anggota kelompok tani Kube Amerta Abadi, Candikuning, 
Baturiti, Tabanan dapat dirinci sebagai berikut :

Tabel 2.

Distribusi Frekuensi Upaya K3 dalam

Berbagai Tahapan Pengamanan

\begin{tabular}{ccccc}
\hline \multirow{2}{*}{ Tahapan Pengamanan } & \multicolumn{2}{c}{ Ketegori Implementasi Upaya K3 } \\
\cline { 2 - 5 } Penggunaan Pestisida & \multicolumn{2}{c}{ dalam Penggunaan Pestisida } \\
\cline { 2 - 5 } & \multicolumn{2}{c}{ Baik } & \multicolumn{3}{c}{ Buruk } \\
\cline { 2 - 5 } & $\mathrm{N}$ & $\%$ & $\mathrm{~N}$ & $\%$ \\
\hline Persiapan & 14 & 93 & 1 & 7 \\
\hline Pelaksanaan & 15 & 100 & 0 & 0 \\
\hline Pasca Pelaksanaan & 6 & 40 & 9 & 60 \\
\hline
\end{tabular}

a. Tahap Persiapan

Tabel 2 menunjukkan bahwa dari hasil wawancara terhadap 15 petani pada tahap perencanaan, sebanyak 14 petani atau $93 \%$ memiliki upaya K3 yang baik.

Tahap persiapan merupakan tahap awal penggunaan pestisida meliputi beberapa kegiatan yaitu pengamanan pembelian pestisida, penyediaan alat aplikasi, alat pelindung diri (APD), pemahaman arti gambar kemasan, pengangkutan dan penyimpanan pestisida. Implementasi upaya K3 pada tahap persiapan kurang baik yaitu seluruh petani tidak menggunakan APD yang lengkap. Pestisida masuk ke dalam tubuh dapat melalui berbagai cara, antara lain melalui pernafasan atau penetrasi kulit. Pemakaian APD menunjukkan masih banyak petani yang kurang memperhatikan keselamatan pada saat menyemprot. Hal ini menunjukkan bahwa pengetahuan petani masihlah kurang tentang risiko bahaya pestisida sehingga bertindak dengan perilaku yang tidak aman. Sesuai dengan penelitian Marina br Karo (2013) ${ }^{4}$ bahwa sikap dan tindakan petani yang kurang mendukung adalah petani kurang setuju terhadap pemakaian APD, karena dianggap mengganggu dan kurang nyaman digunakan.

Oleh karena itu pemakaian APD yang lengkap disarankandigunakan untuk semua kegiatan pengelolaan pestisida yaitu google, respirator, overall/apron, glove dan sepatu boot ${ }^{5}$.

b. Tahap Pelaksanaan

Dari tabel 2 menunjukkan bahwa dari hasil wawancara terhadap 15 petani pada tahap pelaksanaan, selurunya memiliki upaya K3 yang baik. Tahap pelaksanaan merupakan tahap dimana pestisida mulai diapalikasikan yang terdiri dari cara mencampur pestisida, dan cara aplikasi. Dari hasil wawancara terdapat beberapa upaya yang masih kurang baik yaitu aflikasi penyemprotan yang melawan arah angin. Dengan tidak mengikuti arah angin petani berisiko terpapar pestisida seperti terpercik atau terkena langsung ke bagian tubuh dan pakaian akibat hembusan angin yang berbalik ke arah tubuh penyemprot ${ }^{6}$.

Oleh karena itu petani diharapkan menggunakan teknik tidak melawan arah angin saat menyemprot dan tetap menggunakan alat pelindung diri yang 
wajib dikenakan untuk meminimalkan masuknya pestisida lewat jalur pernapasan, kulit dan pencernaan

c. Tahap Pasca Pelaksanaan

Tabel 2 menunjukkan bahwa penggunaan pestisida pada tahap pasca pelaksanaan, sebanyak 9 petani atau $60 \%$ mempunyai upaya K3 yang buruk.

Tahap pasca pelaksanaan menekankan pada pengamanan setelah melakukan penyemprotan. Berdasarkan hasil wawancara seluruh anggota kelompok tani menyatakan tidak pernah dilakukan pemeriksaan kesehatan secara rutin oleh petugas kesehatan. Petani tidak mengetahui seberapa banyak telah terpapar oleh pestisida, padahal pemeriksaan kadar pestisida dalam darah (pemeriksaan cholinesterase) perlu dilakukan guna memonitoring keracunan pestisida dalam tubuh petani ${ }^{7}$.

\section{Implementasi Upaya $\mathrm{K3}$ dalam Penggunaan Pestisida}

Tabel 3.

Distribusi Frekuensi Implementasi Upaya K3 dalam Penggunaan Pestisida

\begin{tabular}{ccc}
\hline $\begin{array}{c}\text { Implementasi } \\
\text { Upaya K3 }\end{array}$ & Frekuensi & $\begin{array}{c}\text { Presentase } \\
(\%)\end{array}$ \\
\hline Baik & 8 & 53 \\
Sedang & 7 & 47 \\
Buruk & 0 & 0 \\
\hline Total & 15 & 100 \\
\hline
\end{tabular}

Tabel 3 menunjukkan bahwa ada 8 petani memiliki upaya K3 baik, dan 7 sedang. Mengaplikasikan pestisida terutama saat menyemprot merupakan pekerjaan yang paling sering menimbulkan kontaminasi jika dibandingkan dengan tahapan yang lain. Namun, yang paling berbahaya adalah saat mencampur pestisida karena pestisida masih dalam bentuk konsentrat (kadar tinggi).

Diperlukan kesadaran pada petani untuk mengubah perilaku pengelolaan pestisida guna mengurangi dampak - yang ditimbulkan, perlu upaya pemberian pelatihan keselamatan dan kesehatan kerja kepada seluruh anggota petani yang menggunakan pestisida.

\section{Tingkat Keracunan Pestisida}

Tingkat keracunan pestisida dikelompokkan menjadi 3 sesuai dengan pedoman Depkes RI (1992) yaitu keracunan ringan, sedang dan berat. Tingkat keracunan petani sesuai hasil penelitian seperti pada table 4 . 
Tabel 4.

Distribusi Frekuensi Tingkat Keracunan

Pestisida Pada Kelompok Tani

\begin{tabular}{ccc}
\hline $\begin{array}{c}\text { Tingkat } \\
\text { Keracunan }\end{array}$ & Frekuensi & $\begin{array}{c}\text { Presentase } \\
(\%)\end{array}$ \\
\hline Ringan & 4 & 27 \\
Sedang & 11 & 73 \\
\hline Total & 15 & 100 \\
\hline
\end{tabular}

Dari hasil uji kadar cholinestarase

darah menggunakan Test-mate ChE

Cholinestarase Test System (Model 400) terhadap 15 petani sebanyak 4 petani mengalami keracunan ringan, 11 petani mengalami keracunan sedang dan tidak ada petani yang mengalami keracunan berat.

Dari hasil penelitian menunjukkan bahwa petani mengalami keracunan ringan atau over exposure dan keracunan sedang atau over exposure serius, dimana diperlukan juga uji ulang terhadap tingkat keracunan petani. Jika benar, petani dihimbau untuk istirahat dari semua pekerjaan yang berkenaan dengan pestisida (insektisida). Jika yang bersangkutan mengalami kondisi sakit, segera dirujuk pada pemeriksaan medis.

Penggunaan pestisida sedapat mungkin dihindarkan atau pilihan terakhir apabila cara pengendalan hama yang lain tidak memungkinkan
5. Hubungan Implementasi Upaya K3 dengan Tingkat Keracunan Pestisida

Tabel 5.

Hubungan Upaya K3 dengan Tingkat

Keracunan Pestisida Kelompok Tani

\begin{tabular}{cccc}
\hline Implementa & \multicolumn{3}{c}{ Tingkat Keracunan } \\
\cline { 2 - 4 } si Upaya & Ringan & Sedang & Total \\
K3 & & & \\
\hline Baik & 4 & 4 & 8 \\
& $(50 \%)$ & $(50 \%)$ & $(100$ \\
& & & $\%)$ \\
Sedang & 0 & 7 & 7 \\
& & $(100$ & $(100$ \\
& & $\%)$ & $\%)$ \\
\hline
\end{tabular}

Tabel 5 menunjukkan bahwa dari 8 petani yang memiliki implementasi upaya K3 yang baik, sebanyak 4 (50\%) petani mengalami keracunan ringan dan 4 (50\%) petani mengalami keracunan sedang. Diketahui pula dari 7 (100\%) petani yang memiliki implementasi upaya K3 sedang, seluruhnya mengalami keracunan sedang dan tidak ada petani yang mengalami keracunan ringan. Dapat diketahui bahwa terdapat hubungan yang nyata implementasi upaya $\mathrm{K} 3$ dalam penggunaan pestisida dengan tingkat keracunan pestisida

Hasil penelitian ini sejalan dengan penelitian yang dilakukan oleh Pujiono pada tahun 2009 yang menyatakan bahwa 
ada hubungan antara praktek pengelolaan penggunaan pestisida dengan kejadian keracunan pestisida di Kabupaten Subang ${ }^{8}$. Praktek penanganan pestisida buruk mempunyai resiko 17 kali lebih besar terkena keracunan pestisida dibandingkan petani yang baik dalam praktek penanganan pestisida.

Mekonnen dan Agonafir (2002) menyatakan bahwa pengelolaan pestisida yang baik merupakan cara yang paling penting dalam mencegah keracunan akibat pestisida. Selain itu diperlukan upaya upaya untuk meningkatkan upaya $\mathrm{K} 3$ melalui kegiatan pelatihan dan memberikan akses petani terhadap teknologi alternatif seperti penerapan PHT, penggunaan biopestisida dalam perlindungan tanaman ${ }^{9}$.

\section{SIMPULAN DAN SARAN}

1. Karakteristik umur petani pada kelompok tani Kube Amerta Abadi sebagian besar berumur 40 - 50 tahun dengan masa kerja lebih dari 10 tahun.

2. Implementasi upaya K3 dalam penggunaan pestisida dari 15 petani pada tahap perencanaan sebanyak 14 petani memiliki K3 baik, tahap pelaksanaan seluruh petani memiliki K3 baik dan pada tahap pasca pelaksanaan 9 petani memiliki K3 buruk dan 6 petani memiliki K3 baik.
3. Implementasi upaya K3 dalam penggunaan pestisida pada kelompok tani Kube Amerta Abadi yaitu dari 15 petani, 8 petani memiliki K3 baik dan 7 petani memiliki upaya K3 sedang.

4. Hasil pemeriksaan darah pada petani didapatkan petani yang mengalami keracunan sedang sebanyak $11(73 \%)$ orang petani. Petani yang mengalami keracunan ringan sebanyak 4 (27\%).

5. Hasil analisa deskriptif dengan crosstabulation menunjukkan terdapat hubungan antara upaya keselamatan dan kesehatan kerja dalam penggunaan pestisida dengan tingkat keracunan petani pada kelompok tani Kube Amerta Abadi.

Berdasarkan penelitian dapat diberi saran yaitu :

1. Bagi petani disarankan melengkapi dan mengefektifkan penggunaan alat pelindung diri pada saat menggunakan pestisida sehingga kejadian keracunan pestisida dapat dicegah.

2. Perlu adanya penyuluhan /pelatihan dari penyuluh pertanian tentang tata cara pencampuran pestisida yang aman bagi kesehatan.

3. Bagi dinas Dinas Kesehatan dan instansi terkait perlu melakukan pemeriksaan cholinesterase secara rutin danberkala. 


\section{DAFTAR PUSTAKA}

1. Haerani. Penerapan Keselamatan dan Kesehatan Kerja di Bidang Pertanian di Indonesia. J. MKMI 6, 180-184 (2010).

2. Hasibuan, R. Insektisida. (Plantaxia., 2015).

3. Pawukir, Enny S. ( Program Studi Pendidikan Dokter Universitas Jember) ; Mariyono, Joko ( Yayasan Bahtera Indonesia, Y. HUBUNGAN ANTARA PENGGUNAAN PESTISIDA DAN DAMPAK KESEHATAN: STUDI KASUS DI DATARAN TINGGI SUMATRA BARAT. J. Mns. dan Lingkung. (Journal People Environ. Vol 9, 126-136 (2002).

4. Karo, M. br. Pengetahuan, Sikap dan Tindakan Petani Holtikultura dalam Penggunaan Pestisida di Desa Aji Mbelang Kecamatan Tiga Panah Lebih Baik dibandingkan Petani Holtikultura di Desa Deram Kecamatan Merdeka Kabupaten Karo Tahun 2011No Title. PANNMED 8, 73-77 (2011).

5. Yeviana Dwi Rahmawati, T. M. PENGARUH FAKTOR KARAKTERISTIK PETANI DAN METODE PENYEMPROTAN
TERHADAP KADAR

KOLINESTERASE. Indones. $J$.

Occup. Saf. , Heal. Environ. I, 8594 (2014).

6. Mahyuni, E. L. FAKTOR RISIKO

DALAM PENGGUNAAN

PESTISIDA PADA PETANI DI

BERASTAGI KABUPATEN

KARO 2014. J. Fak. Kesehat.

Masy. 9, (2015).

7. Wudianto R. Petunjuk Penggunaan Pestisida. (Penebar Swadaya, 2010).

8. Pujiono. Hubungan Faktor

Lingkungan Kerja Dan Praktek

Pengelolaan Pestisida Dengan

Kejadian Keracunan Pestisida

Pada Tenaga Kerja Di Tempat

Penjualan Pestisida Di Kabupaten

Subang. (Pascasarjana Undip, 2009).

9. Istianah $\square$, A. Y. Hubungan Masa Kerja, Lama Menyemprot, Jenis Pestisida, Penggunaan APD dan Pengelolaan Pestisida dengan Kejadian Keracunan Pada Petani di Brebes. Public Heal. Perspect. J. 2, 117-123 (2017). 